\title{
Analysis of Snow Cover in River Drainage basin Based on MODIS Data
}

\author{
Xieraili Abudurexiti ${ }^{1}$, Meiliguli Maimaiti ${ }^{2 *}$ \\ ${ }^{1}$ Xinjiang Ertix River Basin Development and Construction Management Bureau, Urumqi Xijiang, 830000, China \\ ${ }^{2}$ Xinjiang Institute of water resources and Hydropower Research, Urumqi Xijiang, 830049, China
}

\begin{abstract}
In this paper, MODIS snow cover remote sensing data and Geographic Information System (GIS) technology were used to analyze extraction methods of the snow cover area information. And taking a river drainage basin as an example, this paper studied the variation characteristics of snow cover area in mountainous watershed from 2005 to 2007 in spring and summer to further provide a basis and reference for understanding the process of snowmelt in this drainage basin. The results show that the snow cover area of the river drainage basin has gradually decreased from March, and the smallest snow cover area in the drainage basin appeared in July. The snow cover area has gradually increased since August, and the annual snow melting period is from April to July.
\end{abstract}

\section{Introduction}

The mountain snow is an important source of water in arid and semi-arid regions and a major source of runoff for inland rivers. Snow often accumulates in the form of snowfall in winter, and gradually melts into snowmelt runoff as the temperature rises in spring and summer. Xinjiang is a arid and semi-arid region in the northwestern border of China. It is located in the hinterland of the Central Asian continent, which is far from the ocean and has little precipitation, large evaporation and lack of runoff. Snowmelt water and precipitation runoff are the most precious water resources of the local people and an important guarantee for life, production and ecological environment construction. There are more than 570 river runoffs in Xinjiang, with the snow-covered areas of the mountains such as Tianshan and Kunlun Mountains as the source. The change of snowmelt process will lead to large changes in runoff volume and runoff time distribution, which will further affect hydrological processes and water resources in oasis and desert areas in arid regions. Therefore, it is of great practical significance to study the dynamics of snow-covered spatial and temporal changes in mountainous watersheds of Xinjiang.

Taking a river drainage basin on the northern slope of the Tianshan Mountains in Xinjiang as an example, and based on 8-days' maximum synthesis snow cover data of Moderate-resolution Imaging Spectroradiometer (MODIS) and land satellite-Terra, which product code is MOD 10A2, and is frequently used in snow cover analysis, this paper analyzes the variation characteristics of snow cover in the river drainage basin from spring to summer from 2005 to 2007 , so as to provide a scientific basis for understanding the snowmelt process in the drainage basin and provides reference for calculating snow cover information in other drainage basins in Xinjiang.

\section{Watershed overview and data sources}

The river drainage basin is located in the middle of the northern slope of the Tianshan Mountains, on the southern margin of the Junggar drainage basin. It is located between $84^{\circ} 43^{\prime} \mathrm{E} \sim 86^{\circ} 35^{\prime} \mathrm{E}$ and $43^{\circ} 03^{\prime} \mathrm{N} \sim 45^{\circ} 20^{\prime} \mathrm{N}$ It belongs to the typical glacial snowmelt. The mountain stream river with water and rainfall mixed supply has a total length of about $400 \mathrm{~km}$ and a drainage area of $2.67 \times 104 \mathrm{~km}^{2}$. After the tributaries of the drainage basin meet, they flow out into the piedmont plain at the Ken Swart Hydrological Station.

Digital elevation model data is obtained at http://strm.csi.cgiar.org with a spatial resolution of $30 \mathrm{~m}$. The remote sensing data uses NASA's MOD 10A2, which is a snow-covered product that is synthesized every 8 days with a resolution of $500 \mathrm{~m}$.

\section{Research method}

\subsection{Data extraction from the river drainage basin}

Using DEM data and the slope flow simulation method in the extended module-Arc Hydro Tools of the geographic information system software ArcGIS platform, and through the process of filling the ground, calculating the flow direction, calculating the flow accumulation and river grid generation, the data of Ken

*Corresponding author's e-mail: 49463385@qq.com (Meiliguli) 
Swart hydrology station-controlled mountain drainage basin were extracted.

\subsection{Snow cover information extraction algorithm}

The snow cover area is extracted and calculated using MODIS snow data. MODIS data has the advantages of good spectral resolution and good time resolution, which provides good conditions for snow cover mapping applications in mountainous areas. It has high geolocation accuracy and the snow data can be read directly without classification between surface coverings. In 2002, Hall et al. proposed a 500m resolution MODIS snow cover mapping algorithm to calculate the Normalized Differential Snow Index (NDSI) using MODIS 4th band $(0.545 \sim 0.565 \mu \mathrm{m})$ and 6th band

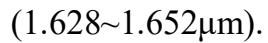

$$
N D S I=\frac{M O D I S_{B 4}-M O D I S_{B 6}}{M O D I S_{B 4}+M O D I S_{B 6}}
$$

When NDSI $\geq 0.4$ or MODIS 2nd band $(0.841 \sim$ $0.876 \mu \mathrm{m}) \geq 11 \%$, the area is divided into snow cover area, and when the 4th band reflectance $\leq 10 \%$, the area is divided into snow-free cover area. Use the above algorithm to generate MODIS snow cover data. MOD $10 \mathrm{~A} 1$ is the daily snow cover data. The MOD 10A2 8 days maximum snow cover data, which is commonly used for snow cover analysis, can be obtained by continuous 8 days of snow cover daily product MOD $10 \mathrm{~A} 1$ data synthesis.

\section{Results and analysis}

The slope flow simulation method was used under the ArcGIS platform to extract the mountain drainage basin boundary of the river from the DEM data. The drainage area of the river mountain area is $4633 \mathrm{~km}^{2}$, the elevation is from 886 to $5138 \mathrm{~m}$, and the average elevation is $2968 \mathrm{~m}$. The results are shown in Figure 1.

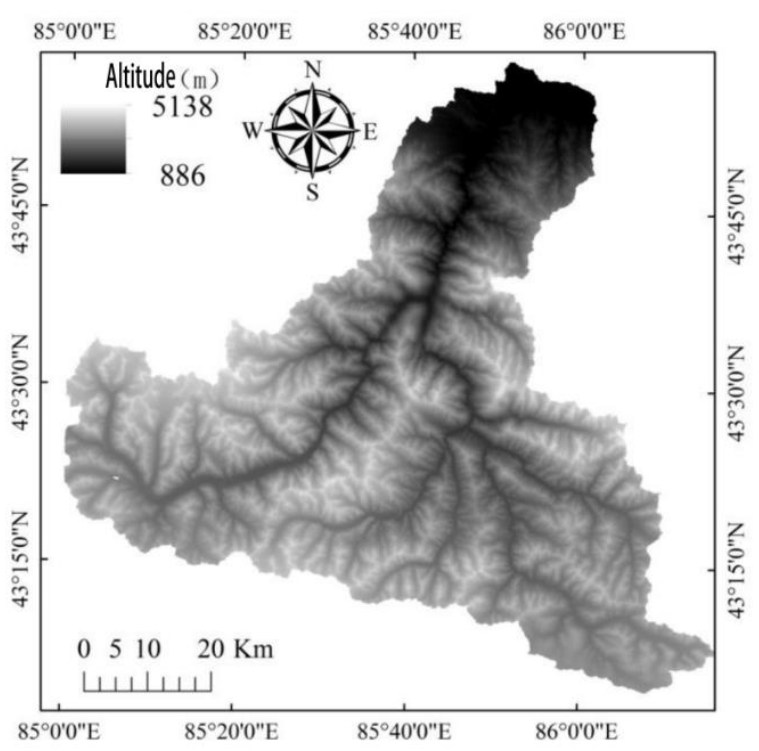

Figure 1. Mountain basin boundary.

After extracting the drainage basin boundary, the Modis Reprojection Tools software is used to convert and transform the MOD 10A2 data. The WCS_1984_UTM_Zone_45N projection coordinates are used, and the drainage basin boundary line and the snow cover data are superimposed and cropped to obtain the snow cover information of the drainage basin. The snow cover information extraction in the river drainage basin is based on the snow cover change in the spring and summer from 2005 to 2007, and the changes in the average snow cover area in each year are analyzed.

The MOD 10A2 data continuously has an image in every 8 days, and there are 24 images from March to August each year. The snow cover area first calculates the snow cover area of each scene image, and then takes the average value of the spring and summer 24 scene images to obtain the snow cover area change data of the drainage basin from 2005 to 2007. The results are shown in Table 1:

Table 1. Statistical table of snow cover area of the river Basin in the spring and summer of 2005-2007 based on MOD 10A2 data (unit: $\mathrm{km}^{2}$ )

\begin{tabular}{ccccccc}
\hline Month & March & April & May & June & July & August \\
\hline 2005 & 2198.25 & 1751.13 & 1065.81 & 858.50 & 577.69 & 1513.69 \\
2006 & 1663.00 & 1753.33 & 1517.50 & 718.42 & 833.92 & 830.08 \\
2007 & 1626.06 & 1664.75 & 1316.75 & 807.69 & 951.13 & 1085.25 \\
Three-year average & 1829.10 & 1723.07 & 1300.02 & 794.87 & 787.58 & 1143.01 \\
\hline
\end{tabular}

As shown in Table 1, the snow cover area of the river drainage basin began to decrease with the increase of temperature from March, and reached its minimum value in July (except in 2007), and then the area of snow began increase with the drainage basin temperature decrease in August.

For the three-year average snow cover area, the snow cover areas were the largest in March of the spring and summer, reaching $1892.10 \mathrm{~km}^{2}$, accounting for $39.51 \%$ of the total area of the drainage basin; in July, the snow cover area is the smallest, and its proportion in the drainage basin area is reduced as small as $17.01 \%$. Figure 2 shows the monthly proportion variation of total drainage basin snow cover area in the spring and summer from 2005 to 2007, it can be seen that, in the river drainage basin, the snow melt mainly occurs from April to July, generating snowmelt runoff to the basin. 


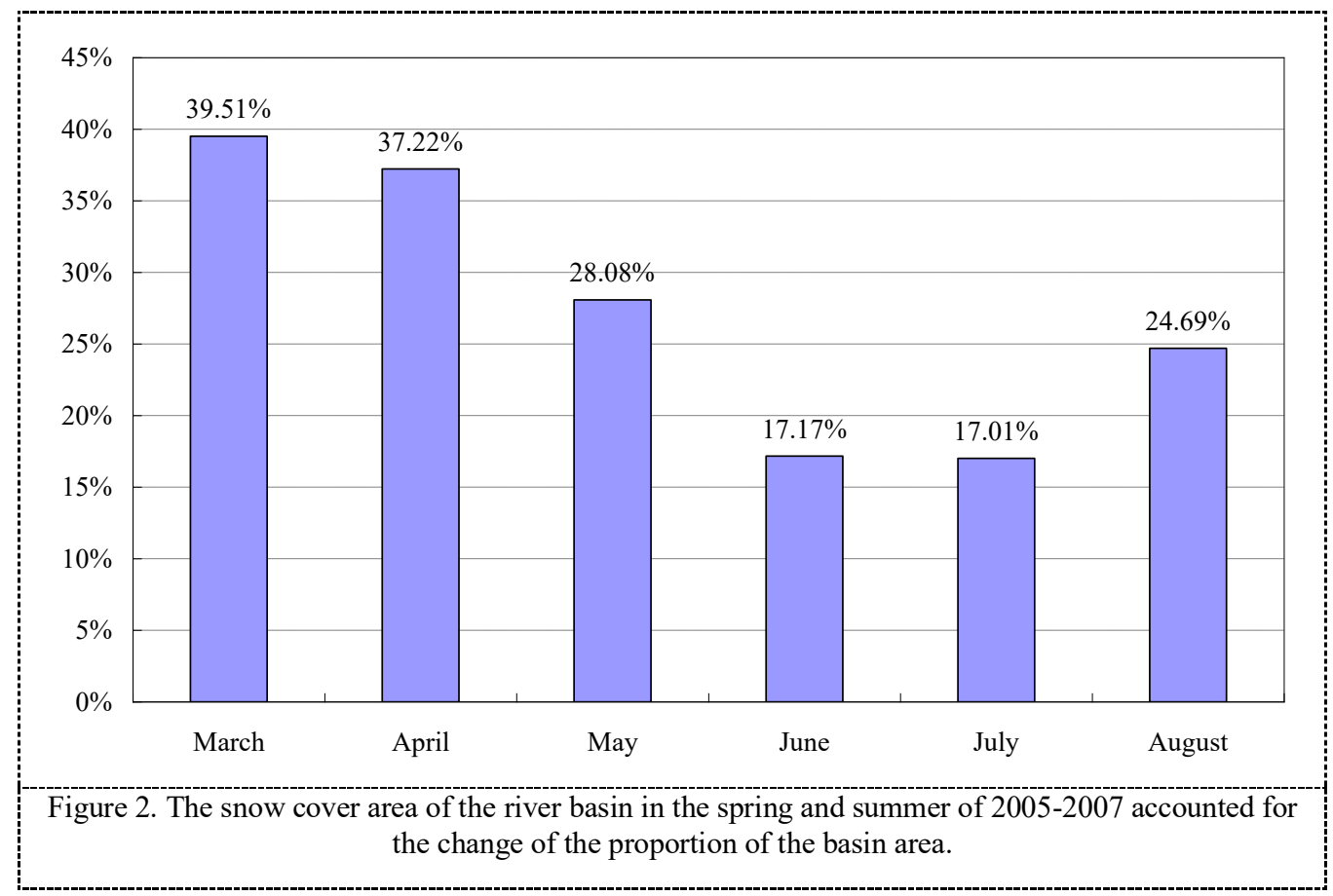

\section{Conclusion}

This paper mainly uses remote sensing and GIS technology to analyze the seasonal variation of snow cover area in the river drainage basin from 2005 to 2007 based on MODIS snow cover data. The results show that the snow cover area of the river drainage basin gradually decreased from March with the temperature rise, the minimum snow cover area of the drainage basin appeared in July, and the snow cover area gradually increased from August. The snow melting period in the river drainage basin is from April to July each year.

\section{References}

1. Li H, Xiao P, Feng X, et al. Monitoring snow depth and its change using repeat-pass interferometric SAR in Manas River Basin[C]//2016 IEEE International Geoscience and Remote Sensing Symposium (IGARSS). IEEE, 2016: 4936-4939.

2. Wang L X, Feng X Z, Xiao P F. Effect factors of satellite snow cover extraction in Manas River Basin, Xinjiang[J]. Remote Sensing Information, 2011, 5: 31-37.

3. Qunzhu F X L A Z. Study on Snow Disaster Monitoring and Assessment Using Remote Sensing in the Main Pastoral Areas of China $[\mathrm{J}][\mathrm{J}]$. Journal of Remote Sensing, 1997, 2.

4. Parajka J, Bezak N, Burkhart J, et al. MODIS snowline elevation changes during snowmelt runoff events in Europe[J]. Journal of Hydrology and Hydromechanics, 2019, 67(1): 101-109.

5. Bair E H, Rittger K, Skiles S M K, et al. An examination of snow albedo estimates from MODIS and their impact on snow water equivalent reconstruction[J]. Water Resources Research, 2019.

6. Sahu R, Gupta R D. Snow Cover Analysis in Chandra Basin of Western Himalaya from 2001 to 2016[M]//Applications of Geomatics in Civil Engineering. Springer, Singapore, 2020: 557-566.

7. Faiz M A, Liu D, Tahir A A, et al. Comprehensive evaluation of $0.25^{\circ}$ precipitation datasets combined with MOD10A2 snow cover data in the ice-dominated river basins of Pakistan[J]. Atmospheric Research, 2020, 231: 104653.

8. Johnston K, Ver Hoef J M, Krivoruchko K, et al. Using ArcGIS geostatistical analyst[M]. Redlands: Esri, 2001. 